\title{
Impact of untreated dental caries on oral health of adolescents from cities in the countryside of Rio Grande do Sul
}

¿open acess

${ }^{1}$ Acadêmica do curso de Odontologia da Faculdade Meridional/IMED de Passo Fundo (RS), Brasil.

${ }^{2}$ Professora Doutora do curso de Odontologia da Faculdade Meridional/ IMED de Passo Fundo (RS), Brasil.

\section{Corresponding author:}

lilia.nrigo@imed.edu.br

Manuscript received: May 2018

Manuscript accepted: October 2018

Version of record online: November 2018
Paola Tibolla ${ }^{1}$, Lilian Rigo ${ }^{2}$

\begin{abstract}
Introduction: Dental caries is a major public health problem around the world, because it can cause pain and suffering to individuals. Even with a decline in childhood disease in recent years, it is observed in many countries.
\end{abstract}

Objective: The objective of this research is to analyze the mean of dental caries and the prevalence of untreated caries and associated factors in students from the southern region of Brazil.

Methods: The approach of this study is quantitative, with a cross-sectional design. The research sample was composed of 77 adolescents from the state schools of the urban area of the municipalities of Ciríaco and David Canabarro, Rio Grande do Sul, Brazil. For the data collection, clinical exams were performed, using the DMFT index, and the application of two semistructured questionnaires to adolescents and their parents. The data were analyzed by descriptive statistics and inferential statistics to the Pearson chi-square test and ANOVA at a significance level of $5 \%$.

Results: The prevalence of untreated dental caries in the final sample was $40.3 \%$ and the DMFT index (decayed, missing and filled teeth) 2.32, there was no statistical difference between cities. There was a statistically significant relationship between the variable toothache in the last six months and the outcome of untreated caries $(p=0.012)$ with $76 \%$ of those who had pain. There was also an association between the variable perception of the treatment at the last visit and untreated caries ( $p=0.021$ ), with $84.6 \%$ of adolescents considering poor / regular treatment.

Conclusion: Although the average dental caries has been low, many adolescents have decayed and untreated teeth, with toothache and lack of quality in dental treatment being the factors that most impacted.

Keywords: dental caries, toothache, dmf index, dental care.

Suggested citation: Tibolla P, Rigo L. Impact of untreated dental caries on oral health of adolescents from cities in the countryside of Rio Grande do Sul. Journal of Human Growth and Development. 2018; 28(3):258-272. DOI: http://dx.doi.org/10.7322/jhgd.152171 


\section{INTRODUCTION}

Caries and periodontal disease are the most prevalent oral diseases from the point of view of public health, thus causing a great impact on the quality of life of the individuals affected by them. For this reason, such diseases are addressed in several epidemiological studies, and their results are important for the development of preventive and oral health promotion measures ${ }^{1}$.

In particular, dental caries is a major public health problem worldwide, as it can cause pain and suffering to individuals. Even with a decline of the disease in children in recent years, it is observed in many countries, prevalence still remains high, with records from several countries having a prevalence greater than $50 \%$ in children 12 years of age 2 .

Dental pain, which can be caused by untreated dental caries, is also a public health problem in many countries, including Brazil ${ }^{3}$. Due to its high prevalence, this pain is one of the main causes of suffering and with social, psychological and economic consequences in the affected individuals, resulting in a compromise of quality of life and bringing impacts to society. In addition, dental pain has been pointed out by individuals, including children, as the main reason for seeking dental care ${ }^{4}$. It is relatively common for school-age children to present high prevalence of dental pain, which is mainly caused by untreated dental caries and related to poor oral health conditions ${ }^{5}$.

Dental caries can be influenced by environmental factors, lifestyle and socioeconomic conditions. However, there are limitations and difficulties to its control, and in most of the world it remains untreated, particularly in the socioeconomically disadvantaged populations, affecting children and adolescents to a large extent ${ }^{6}$.

In recent years, the social condition has been highlighted in the evaluation of dental caries, being considered as a factor of relevance for the risk of caries ${ }^{2}$. Low income, represented by the difficulty of accessing dental services and hygiene products, together with the lack of information and knowledge about oral hygiene habits, is associated with the prevalence and severity of dental caries $^{7-9}$. Many epidemiological studies describe the association between social status and poor oral health status $^{7-10}$. There is evidence that the distribution of caries in populations is unequal and commonly associated with socioeconomic status. Thus, studies on the factors that determine oral diseases have gained more importance and usually include socioeconomic factors, such as schooling, individual or family income, and occupation of individuals ${ }^{2}$.

In this context, it is extremely important to carry out an epidemiological survey in municipalities that have not yet been carried out, such as the one developed in the present study, which intends to serve as a basis for assessing the current situation and for monitoring these indicators. In addition, it will be possible to assess the impact of possible changes, which must be achieved through the development of preventive, educational and oral health promotion measures in the population.

The objective of this research is to analyze the mean of dental caries and the prevalence of untreated caries and associated factors in school children in the southern region of Brazil

\section{METHODS}

For ethical questions, the project was submitted to the approval of the Research Ethics Committee of the Southern Faculdade Meridional/IMED and approved under number 2,014,434. School principals were also asked to consent to access to schoolchildren, from the Authorization Term of the site. Parents of adolescents were asked to sign a Free and Informed Consent Form in order to confirm their understanding and the release of their children's participation in the present study. Also, the adolescents were asked to sign the Term of Assent, confirming their participation in the accomplishment of this work.

\section{Study Design and Sampling}

The research has a quantitative approach, whose design is cross-sectional. The study population consisted of all 100 students enrolled in the month of July 2016 in the two state schools of the urban area of the municipalities of the interior of Rio Grande do Sul aged between 11 and 12 years. Of these, 60 adolescents were students of the school that belongs to the municipality of David Canabarro and 40 students of the school of the municipality of Ciríaco. Of the total, 54 and 23 students, respectively from the two municipalities, accepted to participate in the study, totaling a sample of 77 adolescents, which characterized a loss of $23 \%$.

\section{Location of the Study}

The municipality of David Canabarro is located in the Northwest region of Rio Grande do Sul, Brazil. With a population of 4,683 inhabitants ${ }^{11}$ and a total area of $174,939 \mathrm{~km}^{2}$. The municipality of Ciríaco is located in the Northwest region of Rio Grande do Sul, Brazil. With a population of 4,922 inhabitants ${ }^{11}$ and total area of 273,873 $\mathrm{km}^{2}$.

\section{Instruments and Procedures for Data Collection}

To collect data, a self-administered questionnaire was used for the students and another one for the parents, with questions related to dental care, risk factors and knowledge about dental caries.

Afterwards, a clinical examination was performed to collect data on dental caries in all adolescents, using the DMFT index (index of decayed, missing and filled teeth). The DMFT index measures the dental caries attack on the permanent dentition. Their initials represent, respectively: decayed (D), missing (M), filled (F) teeth and the unit measure being the tooth $(\mathrm{T})$. The lost are subdivided into extracted and indicated extraction, proposed by Palmer and Klein ${ }^{12}$.

For inclusion criteria, students should be enrolled in the state schools of the urban area of David Canabarro and Ciríaco, accept to participate in the research, by signing the Terms of Consent, and be present at the date of data collection.

Firstly, it was requested the authorization of the place in the state schools of the municipalities, and later, to request the signature of the parents or guardians consenting to participate in the research besides signing the Term of Assentment by the adolescents. 
A questionnaire was sent to parents of adolescents, containing questions related to socioeconomic conditions, access to dental services of their children, using as reference the "Form of socioeconomic evaluation, access to dental services, and self-perception of oral health adopted in SB Brazil 2010. ${ }^{13}$ Both questionnaires were adapted, adding some specific questions to the present study on knowledge about dental caries, methods of prevention and oral hygiene, ingestion of candies and candies and access to the dentist.

Subsequently, a semi-structured questionnaire was applied to students with information on diet, knowledge about dental caries, oral hygiene habits and self-perception of oral health. The questionnaires were delivered to the students in their respective classrooms to be answered. After 1 hour, the rooms were collected to collect the questionnaires, so that the influence of the researcher did not occur. Data collection was carried out in the schools in July 2016, in the morning and afternoon shifts, according to the availability of the schedules by the School Directors and the Teachers present in class, seeking not to interfere with the activities proposed by the schools and the teachers. Afterwards, the data were collected through intraoral clinical examinations, according to the DMFT index for dental caries. The students were called one at a time so that they could be examined properly. Groups composed of flat mouth mirror and sterilized exploratory catheter and tongue depressors were used, following biosafety norms of the Ministry of Health for epidemiological survey. All students were examined next to natural light (window) and with lighting and flashlight help in a room provided by the school heads.

Data were analyzed individually by descriptive statistics and by inferential statistics using the Pearson chi-square test and ANOVA at a significance level of 5\%. Statistical Package for the Social Sciences (SPSS) 20.0 was used for this purpose.

\section{RESULTS}

The analysis identified that of the 77 participants who answered the questionnaire, 54 (70.1\%) lived in the municipality of David Canabarro and the others in Ciríaco and were 11 or 12 years old, $50.6 \%$ female and the other male. Of these, 59 (76.6\%) reported not knowing how tooth decay occurs, but only $3.9 \%$ of them brush their teeth only once a day, unlike the others, who brush twice or more a day and only $33.8 \%$ use dental floss daily. The majority of them have ever been to the dentist, being $98.7 \%$ in the last year, the reasons for which were varied: $54.5 \%$ for review / checkup or prevention, $10.4 \%$ for toothache, and the others for some treatment. The majority had a good perception of the dental treatment performed in the last consultation $(83.1 \%$ ), but $28.6 \%$ believe that they currently require dental treatment.

When the students were questioned about the presence of toothache, $25(32.5 \%)$ reported having suffered toothache in the last 6 months. Thus, 64 (83.1\%) of the students had a good perception of the treatment in the last consultation being satisfied.

When questioned about the frequency of intake of candy or sweets, $23.4 \%$ stated that they ingest every day.
Regarding parents' schooling, 57.2\% attended elementary school, $27 \%$ up to high school and $15.6 \%$ attended higher education. Regarding income, questioned about the amount received monthly, $55.9 \%$ receive from $\mathrm{R} \$ 500$ to $\mathrm{R} \$ 1,500.00$, and the other part (44.1\%) receives from $\mathrm{R} \$ 1,501.00$ to $\mathrm{R} \$ 4,500.00$ monthly. According to the parents, $85.5 \%$ said that access to the dental surgeon is easy and fast, $67.5 \%$ attending public service and $32.5 \%$ attending private service.

The mean DMFT index found in all adolescents was 2.32 (sd 1.81). According to the municipalities, the average of the adolescents of David Canabarro was 2.43 (sd1.93) and that of Ciríaco 2.09 (sd 1.50). According to statistical analysis to verify difference between the groups, it was possible to observe that there was no statistically significant difference between the means of dental caries among the adolescents of the two municipalities, from the Analysis of Variance (ANOVA) test, with $\mathrm{p}=0.45$.

When the components of the DMFT index were analyzed separately, it was verified that the prevalence of untreated dental caries was $40.3 \%$, observed by the sum of the components decayed and filled, but with caries present. In Figure 1, the frequencies of the DMFT components (decayed, missing and filled teeth) are represented (Figure 1).

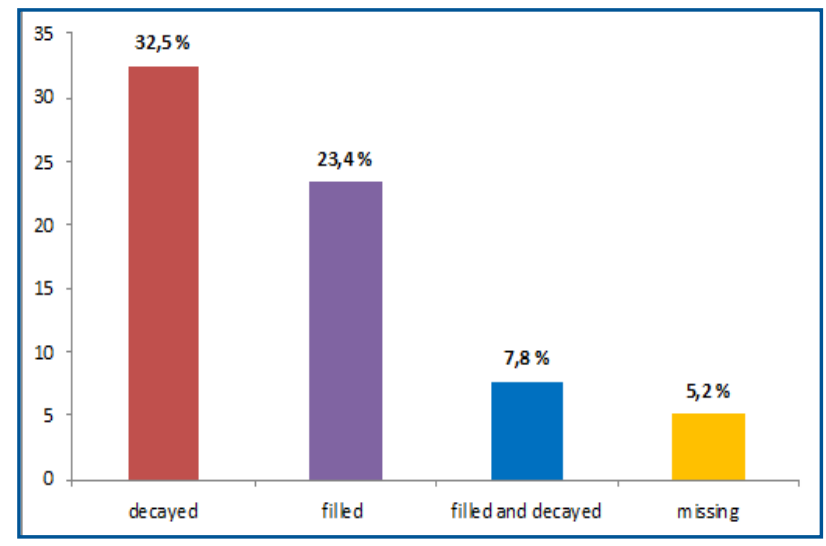

Figure 1: Distribution of the dental caries experience, according to the DMFT components of adolescents from the cities of David Canabarro and Ciríaco, RS, 2016.

For the construction of the dental caries untreated dependent variable, the components of the DMFT were categorized into two groups: 1 . Yes - decayed and filled, but with caries; 2. No caries - all other components.

Bivariate relationships are presented in Tables 1 and 2 , between dependent variable and independent variables (socio-demographic variables and variables of habits and oral perceptions). After statistical analysis, a statistically significant relationship was observed between the variable toothache in the last 6 months and untreated caries with a frequency of $76 \%$ of those who had toothache in the last 6 months and caries present $(\mathrm{p}=0.012)$. Also, there was an association between the variable perception of dental treatment at the last visit and untreated caries $(\mathrm{p}=0.021)$, with $84.6 \%$ of those who considered the treatment as poor and / or regular (Table 1 and Table 2).

The data found in the scientific publications with high evidences and that served for the discussion of the work are in Table 3. 
Table 1: Bivariate analysis between sociodemographic variables and untreated caries in adolescents from the cities of David Canabarro and Ciríaco, RS, 2016.

\begin{tabular}{|c|c|c|c|c|c|}
\hline \multirow[t]{3}{*}{ Variables } & \multicolumn{5}{|c|}{ Untreated caries } \\
\hline & \multicolumn{2}{|r|}{ Yes } & \multicolumn{2}{|c|}{ No } & \multirow[t]{2}{*}{$\mathrm{p}$} \\
\hline & $\mathrm{n}$ & $\%$ & $\mathrm{n}$ & $\%$ & \\
\hline City & & & & & 0.570 \\
\hline David Canabarro & 24 & 44.4 & 30 & 55.6 & \\
\hline Ciríaco & 10 & 43.5 & 13 & 56.5 & \\
\hline Age (years) & & & & & 0.555 \\
\hline 11 & 21 & 43.8 & 27 & 56.2 & \\
\hline 12 & 13 & 44.8 & 16 & 55.2 & \\
\hline Gender & & & & & 0.215 \\
\hline Male & 19 & 50.0 & 19 & 50.0 & \\
\hline Female & 15 & 38.5 & 24 & 61.5 & \\
\hline Education Level & & & & & 0.968 \\
\hline Up to completion of elementary school & 20 & 58.8 & 24 & 55.8 & \\
\hline High schoo & 9 & 26.5 & 12 & 27.9 & \\
\hline Higher education & 5 & 14.7 & 7 & 16.3 & \\
\hline Monthly family income (in Brazilian reais) & & & & & 0.506 \\
\hline $500.00-1.500 .00$ & 15 & 44.1 & 28 & 65.1 & \\
\hline $1.501 .00-4.500 .00$ & 19 & 55.9 & 15 & 34.9 & \\
\hline Last dental consultation & & & & & 0.114 \\
\hline Public Service & 20 & 38.5 & 32 & 61.5 & \\
\hline Private Service & 14 & 56.0 & 11 & 44.0 & \\
\hline Access to the dental surgeon & & & & & 0.505 \\
\hline Easy and fast & 29 & 85.3 & 33 & 76.7 & \\
\hline Regular and difficult & 5 & 14.7 & 10 & 23.3 & \\
\hline
\end{tabular}

${ }^{*} p<0.05$ - Statistically significant difference.

Table 2: Bivariate analysis between variables of habits and oral perceptions and untreated caries in adolescents from the cities of David Canabarro and Ciríaco, RS, 2016.

\begin{tabular}{|c|c|c|c|c|c|}
\hline \multirow[t]{3}{*}{ Variables } & \multicolumn{4}{|c|}{ Untreated caries } & \multirow[b]{3}{*}{$p$} \\
\hline & \multicolumn{2}{|c|}{ Yes } & \multicolumn{2}{|c|}{ No } & \\
\hline & $\mathrm{n}$ & $\%$ & $\mathrm{n}$ & $\%$ & \\
\hline Knowledge of how dental caries occur & & & & & 0.594 \\
\hline Yes & 8 & 44.4 & 10 & 55.6 & \\
\hline No & 26 & 44.1 & 33 & 55.9 & \\
\hline Eat sweets or candy & & & & & 0.594 \\
\hline Once or twice a week & 26 & 76.5 & 33 & 76.7 & \\
\hline Every day & 8 & 23.5 & 10 & 23.3 & \\
\hline Number of use of dental floss & & & & & 0.318 \\
\hline Once a day & 10 & 29.4 & 16 & 37.2 & \\
\hline Once a week & 24 & 70.6 & 27 & 62.8 & \\
\hline Number of toothbrushing per day & & & & & 0.579 \\
\hline Once or twice a day & 12 & 35.3 & 15 & 34.9 & \\
\hline More than twice a day & 22 & 64.7 & 28 & 65.1 & \\
\hline Reason for your last visit & & & & & 0.160 \\
\hline Check up or prevention & 21 & 61.8 & 21 & 48.8 & \\
\hline Toothache, Exodontia, Filled & 13 & 38.2 & 22 & 51.2 & \\
\hline
\end{tabular}


Continuation- Table 2: Bivariate analysis between variables of habits and oral perceptions and untreated caries in adolescents from the cities of David Canabarro and Ciríaco, RS, 2016.

\begin{tabular}{|c|c|c|c|c|c|}
\hline \multirow[t]{3}{*}{ Variables } & \multicolumn{4}{|c|}{ Untreated caries } & \multirow[b]{3}{*}{$\mathrm{p}$} \\
\hline & \multicolumn{2}{|c|}{ Yes } & \multicolumn{2}{|c|}{ No } & \\
\hline & $\mathrm{n}$ & $\%$ & $\mathrm{n}$ & $\%$ & \\
\hline Perception about the last dental appointment & & & & & ${ }^{*} 0.021$ \\
\hline Good & 32 & 50.0 & 32 & 50.0 & \\
\hline Bad/regular & 2 & 15.4 & 11 & 84.6 & \\
\hline Need for dental treatment currently & & & & & 0.145 \\
\hline Yes & 9 & 26.59 & 13 & 30.2 & \\
\hline No & 25 & 73.5 & 30 & 69.8 & \\
\hline Toothache in the last 6 months & & & & & ${ }^{*} 0.012$ \\
\hline Yes & 6 & 24.0 & 19 & 76.0 & \\
\hline No & 28 & 53.8 & 24 & 46.2 & \\
\hline Satisfaction with teeth/mouth & & & & & 0.504 \\
\hline Satisfied & 23 & 67.6 & 25 & 67.4 & \\
\hline Not satisfied & 11 & 32.4 & 14 & 32.6 & \\
\hline
\end{tabular}

${ }^{*} p<0.05$ - Statistically significant difference.

Table 3: Evidences in Scientifics articles.

\begin{tabular}{|c|c|c|c|c|}
\hline Authos/ Year & $\begin{array}{l}\text { Objectives of } \\
\text { the study }\end{array}$ & $\begin{array}{l}\text { Search } \\
\text { Location }\end{array}$ & $\begin{array}{l}\text { Sample (tsize } \\
\text { and age) }\end{array}$ & Results \\
\hline $\begin{array}{l}\text { Hoffmann et al. } \\
(2004)^{17}\end{array}$ & $\begin{array}{l}\text { To verify the } \\
\text { prevalence of } \\
\text { caries among } \\
\text { preschoolers } \\
\text { and } \\
\text { schoolchildren } \\
\text { in a municipality } \\
\text { with fluoridated } \\
\text { water located in } \\
\text { the Southeast } \\
\text { Region of } \\
\text { Brazil and its } \\
\text { relation with the } \\
\text { socioeconomic } \\
\text { level, measured } \\
\text { by the type of } \\
\text { school. }\end{array}$ & $\begin{array}{l}\text { Rio Claro- } \\
\text { SP }\end{array}$ & $\begin{array}{l}888 \text { children } 5 \text { to } \\
12 \text { years old from } \\
\text { public and private } \\
\text { schools. }\end{array}$ & $\begin{array}{l}\text { At } 5 \text { years, the dmtf index was } 2.48 \text {, } \\
\text { increasing until the age of } 8 \text { years; and } \\
42.20 \% \text { had no caries experience. After } \\
\text { this age, the dmtf index decreased to } \\
\text { reach } 0.42 \text { at } 12 \text { years. At the same } \\
\text { time, the DMFT index increased } \\
\text { according to age, reaching a mean of } \\
2.71 \text { at } 12 \text { years, and } 28.90 \% \text { did not } \\
\text { present a caries experience. Dmtf and } \\
\text { DMFT, excluding caries-free children, } \\
\text { did not present a statistical difference } \\
\text { regarding the socioeconomic level, } \\
\text { nor did they differ in the percentage } \\
\text { of children with dmtf higher than } 3 \text {. } \\
\text { A higher percentage of children with } \\
\text { DMFT greater than } 3 \text { were observed in } \\
\text { the group of children in public schools } \\
\text { than in private schools }(p=0.005) \text {. }\end{array}$ \\
\hline $\begin{array}{l}\text { Galindo et al. } \\
(2005)^{8}\end{array}$ & $\begin{array}{l}\text { To verify the } \\
\text { prevalence of } \\
\text { dental caries } \\
\text { and associated } \\
\text { factors in } \\
\text { children } \\
\text { enrolled in the } \\
\text { Family Health } \\
\text { Unit. }\end{array}$ & $\begin{array}{l}\text { Vietnã, } \\
\text { Recife- PE }\end{array}$ & $\begin{array}{l}128 \text { children } \\
6 \text { to } 12 \text { years old. }\end{array}$ & $\begin{array}{l}\text { Of the total, } 14.1 \% \text { of the children } \\
\text { were free of caries. At } 11 \text { and } 12 \\
\text { years, } 29.7 \% \text { had DMFT }=0,29.7 \% \\
\text { had values between } 4-8 . \text { DMFT } \\
\text { decreased significantly with the } \\
\text { increase in family income ( } p=0.02) \text {. } \\
\text { The number of decayed, lost and } \\
\text { restored primary teeth (dmtf) reached } \\
\text { a maximum value at } 7 \text { years ( } 4.50) \text {, } \\
\text { almost significantly higher ( } p= \\
0.05 \text { ) in the families with the highest } \\
\text { number of children up to } 12 \text { years old } \\
\text { (4.50). The educational level of those } \\
\text { responsible, the number of daily } \\
\text { cleanings and access to dental care } \\
\text { did not affect these indices }\end{array}$ \\
\hline
\end{tabular}



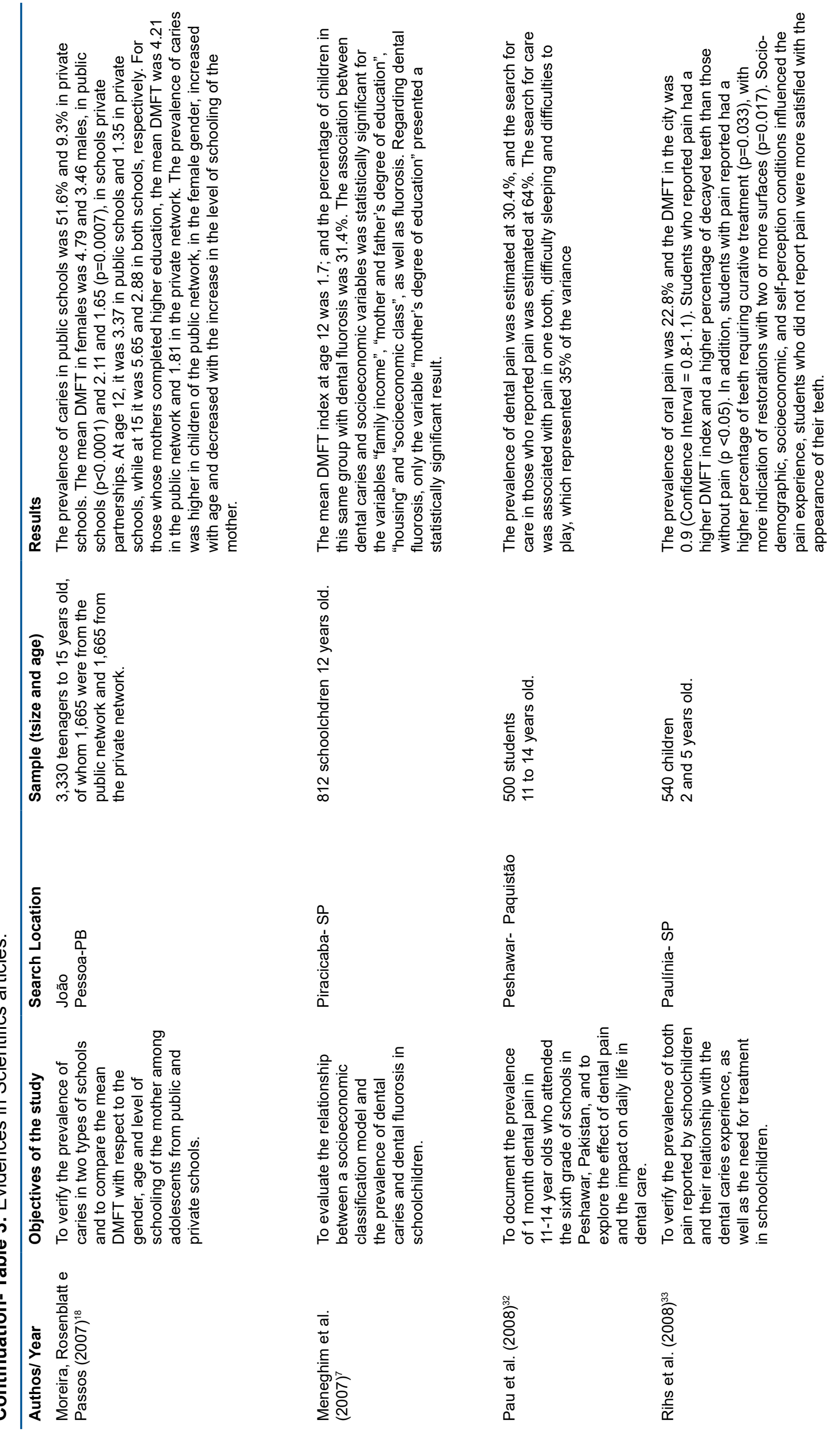

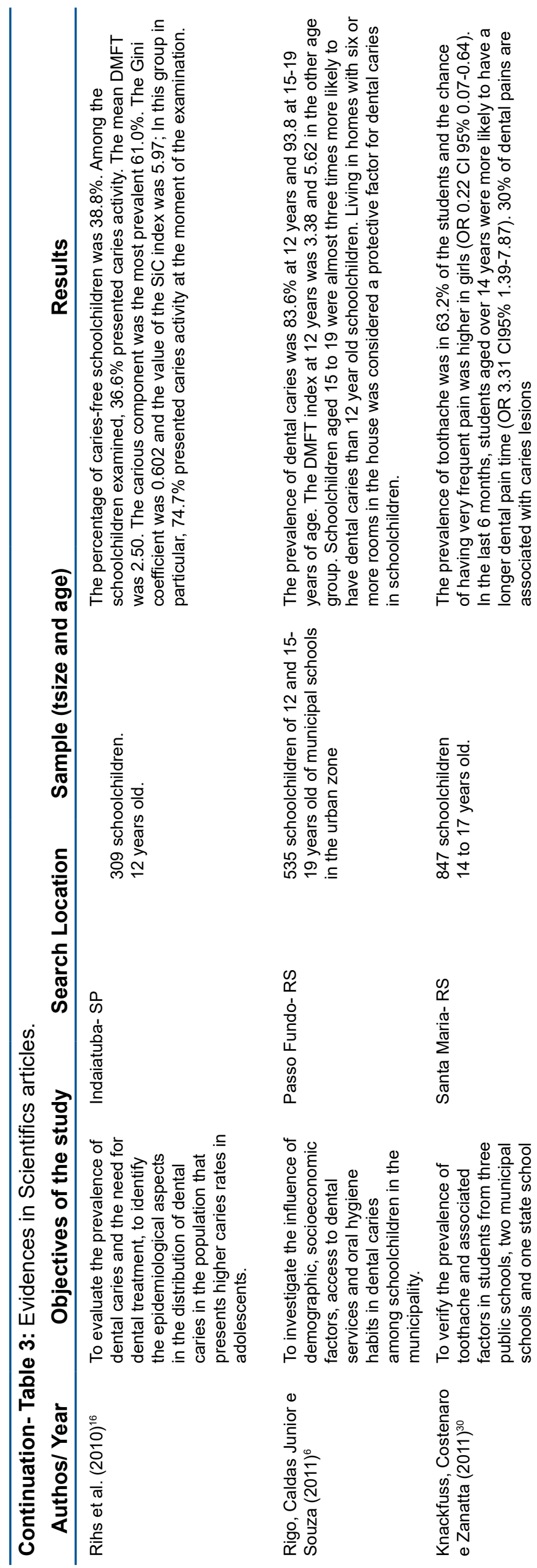

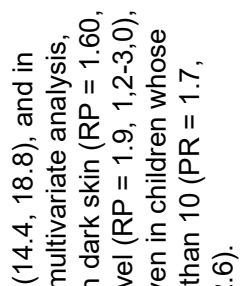

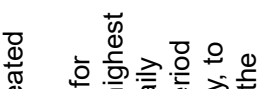

垔

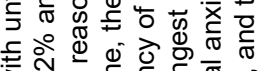

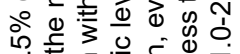

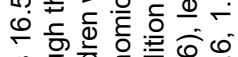

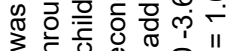

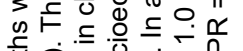

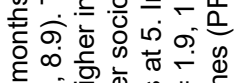

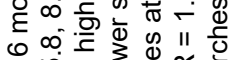

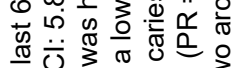

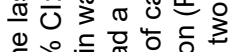

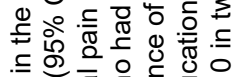

बำ

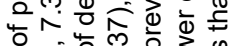

ญ w

市

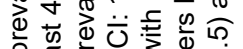

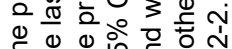

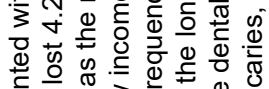

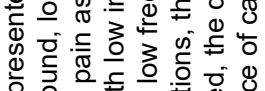

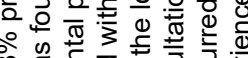

ஸें

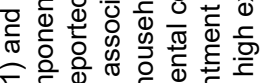

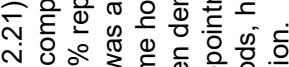

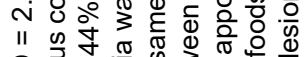

只 은

○.

出

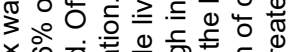

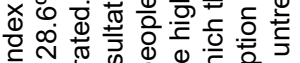

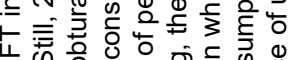

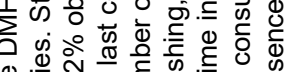

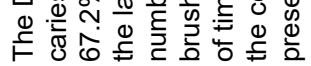
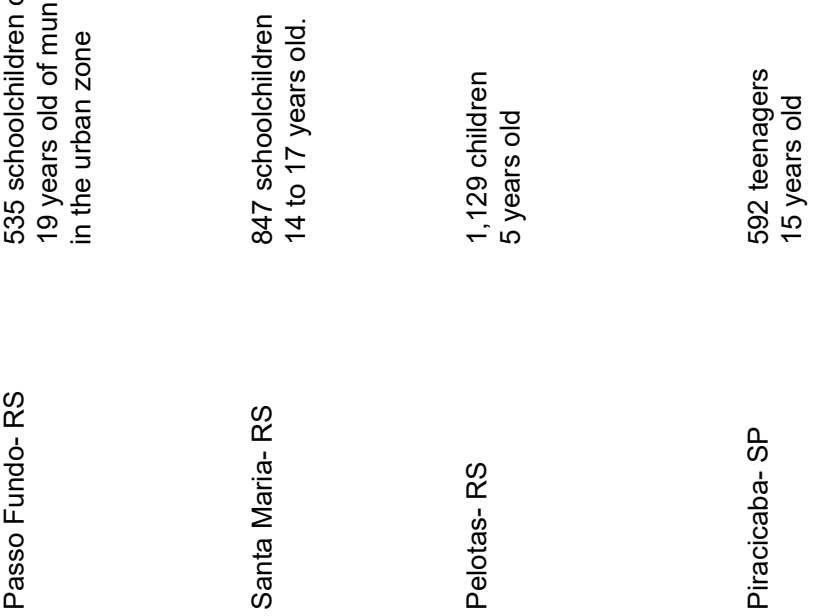

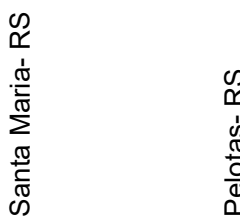

$\begin{array}{ll} & 0 \\ 0 & 0 \\ \frac{1}{10} & \frac{0}{0} \\ \dot{0} & \frac{0}{0} \\ \frac{\pi}{0} & \frac{\pi}{2} \\ \frac{0}{0} & 0\end{array}$
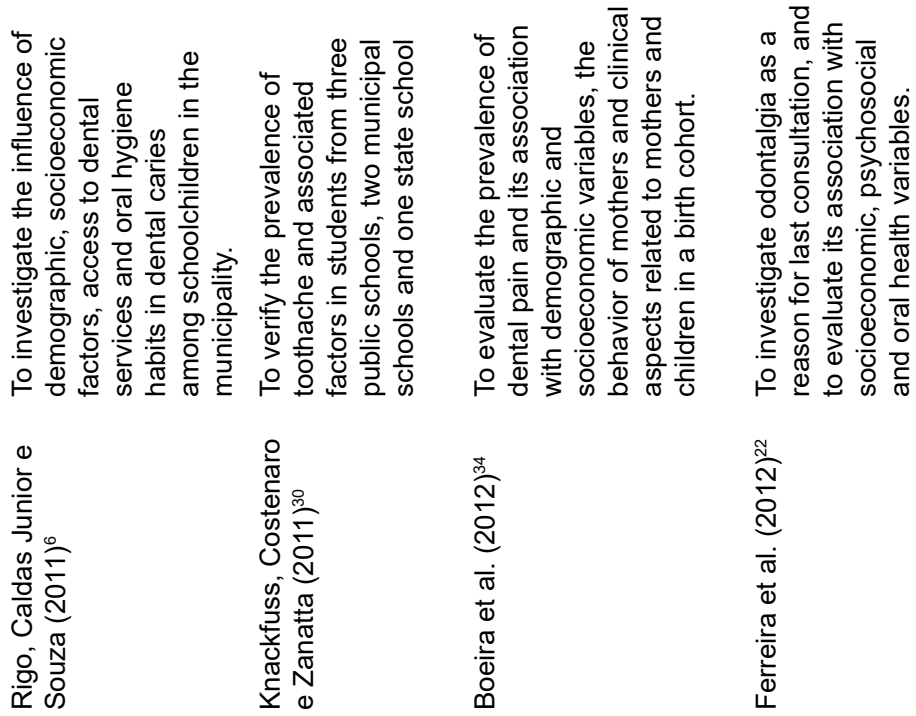

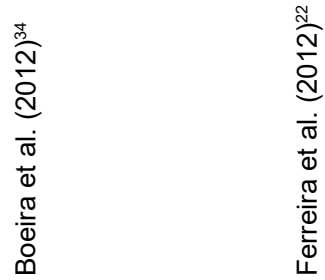




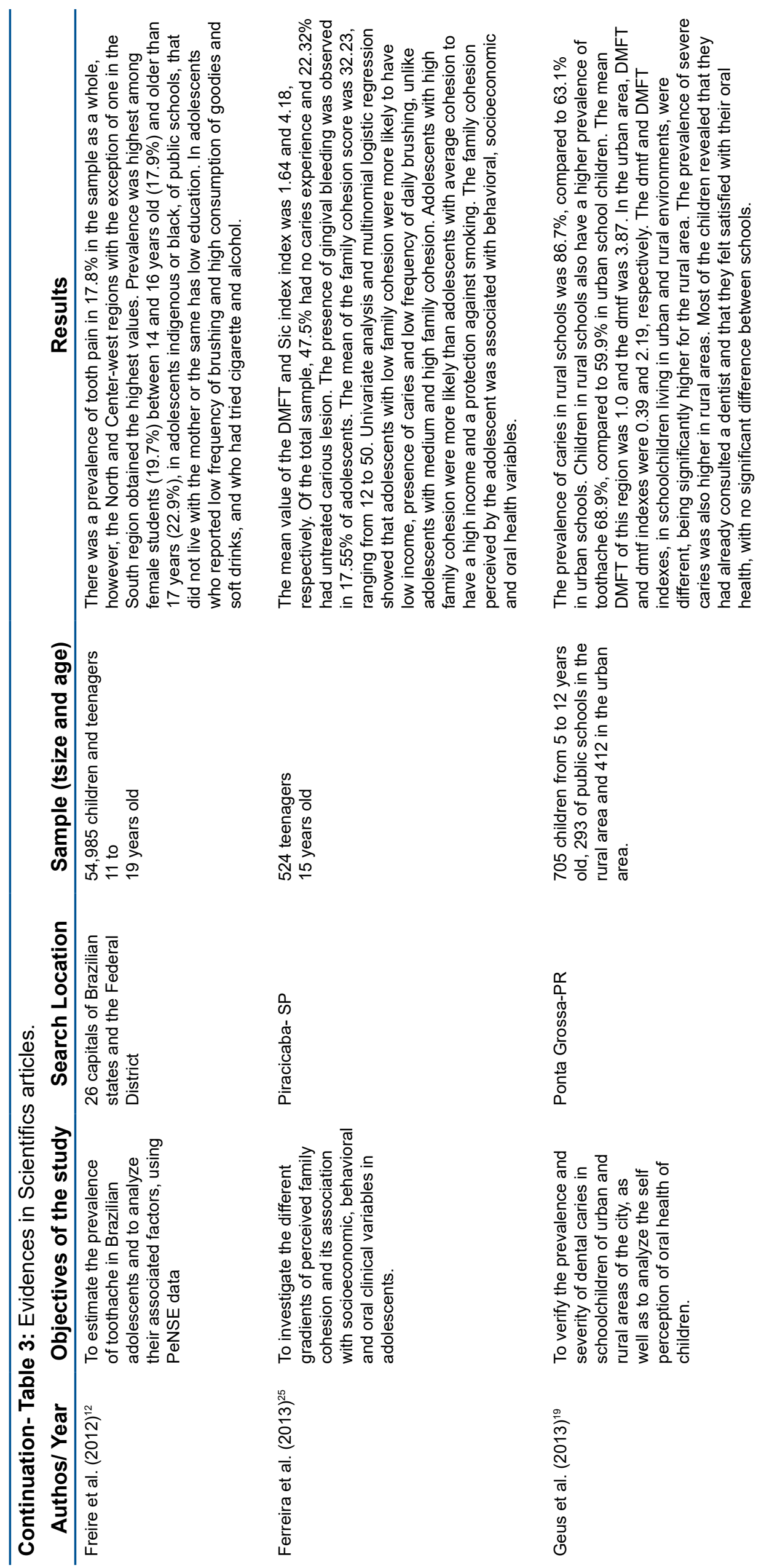




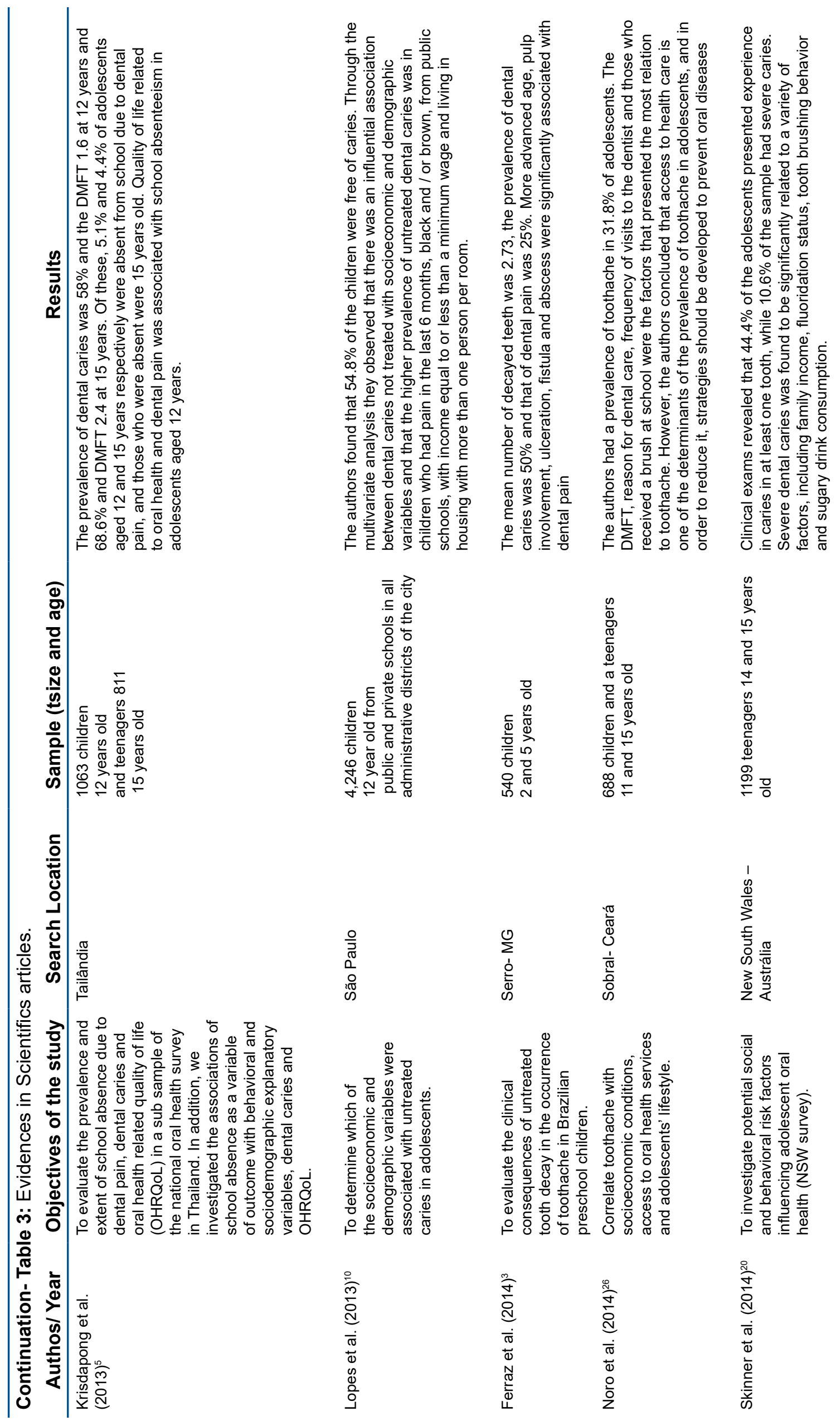




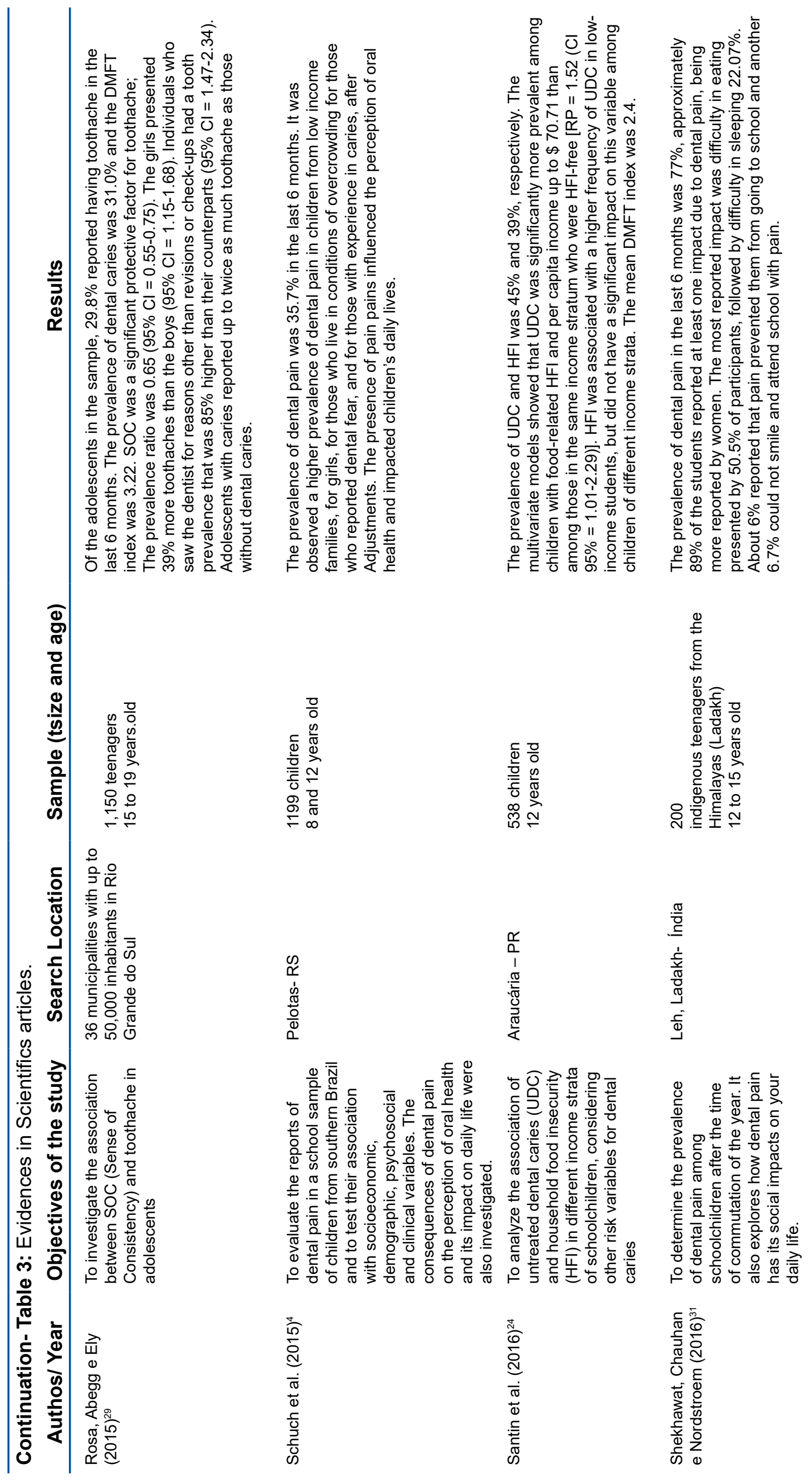




\section{DISCUSSION}

According to the World Health Organization, index values correspond to the following degrees of severity: very low ( 0.0 to 1.1$)$, low (1.2 to 2.6$)$, moderate $(2.7$ to 4,4$)$, high $(4.5$ to 6.5$)$ and very high $(6.6 \text { and more })^{14}$. It's observed that the values obtained in the present study classify the mean of dental caries as low in both municipalities investigated.

The total DMFT index found was 2.32, of which 2.43 in schoolchildren in the municipality of David Canabarro and 2.09 in the schoolchildren of Ciríaco. Similar results were found in the National Oral Health Survey, in which the DMFT was 2.06 in the Southern Region of the country at age ${ }^{12,15}$ as well as in the study by Rihs et al. ${ }^{16}$ in the city of Indaiatuba, SP, in which the DMFT was 2.50. These indi corroborate the data presented in this research. The importance of these oral findings in schoolchildren is of extreme relevance for the Public Health of the municipalities, since the planning of strategies can be formulated from the results demonstrated here.

Differently from these results, some studies found moderate DMFT: in Rio Claro, SP, the authors obtained DMFT 2,717 ; in João Pessoa, PB, 3.37 in public schools and 1.35 in private schools ${ }^{18}$; in Serro, $\mathrm{MG}$, the mean was $2,73^{3}$, and in the municipality of Passo Fundo-RS the DMFT index at 12 years of age was 3,386 . However, better results were still found by Geus et $a l .{ }^{19}$, with a very low DMFT average of only 1.0 in Ponta Grossa, PR, as well as in the National Oral Health Survey, which obtained a mean of 1.49 in Porto Alegre $^{15}$.

The study also aimed to relate the socioeconomic conditions, such as the family income of the students, to the prevalence of dental caries, since findings in the literature showed associations between this variable and the high DMFT. One can cite in this regard the research of Galindo et $a l .^{8}$, which reinforce this statement, since the authors observed that the DMFT decreased significantly with the increase in family income. Other studies corroborating these findings are Freire et $a l .{ }^{2}$, who observed that the caries experience was significantly higher in families with lower income, and that of Skinner et al. ${ }^{20}$, who showed that the experience of dental caries severity was related to several factors, including family income. However, in the present study, there was no statistical significance. This can be attributed to the higher socioeconomic level of the municipalities in which the research was carried out. These municipalities have Human Development Index (HDI) equal to 0.762 in David Canabarro and 0.719 in Ciríaco. This means that both are in the range of high Human Development Index between 0.700 and 0.799 ) and may suggest that there is effective access to health services and goods for their population. With regard to the dimensions that contribute most to the HDI of both municipalities are longevity, income and education ${ }^{21}$. The Gini index (which measures the degree of concentration of income and varies from 0 to 1 , where 0 represents the situation of total equality, and the value 1 means complete inequality of income) of the municipalities is 0.44 in the municipality of David Canabarro and 0.45 in the municipality of $\mathrm{Ciríaco}^{21}$. Thus, the presented indicators are considered good to demonstrate social development in both municipalities. It should also be noted that socioeconomic conditions and the higher level of education and information may be related to lower rates of dental caries among schoolchildren in the municipalities, resulting in a greater demand for dental services.

The variables "last dental consultation", "access to dental services", "frequency of brushing and flossing" had no relation to dental caries not treated in the present study. Although no relation was observed with these variables, the percentage of adolescents who attended the dentist in the last year was $98.7 \%$, and the main reasons for the professional's search were the review, prevention or checkup reported by the students. In addition, the vast majority found access to dental services easy, so much so that $94.8 \%$ of parents reported taking their child to the dentist. With regard to oral hygiene habits, most students reported brushing at least twice a day. According to authors, hygiene habits and access to dental services are important factors for the prevention of dental caries ${ }^{6}$. However, the study by Ferreira et al. ${ }^{22}$ showed different results to those found in the present study, since $33.44 \%$ reported that the reason for the last visit was pain of dental origin, related to the low frequency of daily brushing, to the longest period of time of the last dental visit and high experience of caries. In view of this, it can be inferred that the search for dental services for reviews and oral hygiene habits were frequent in schoolchildren in both municipalities. Results found in the study by Junqueira et $a l .{ }^{23}$ showed a positive relationship between higher rates of health need and the difficulty of access to services, and also lower health needs related to the higher prevalence of children free of dental caries.

The prevalence of untreated dental caries ascertained in this study was $40.3 \%$, similar to the studies by Santin et al. ${ }^{24}$ conducted in Araucária, PR, with 12-year-old adolescents, where the prevalence of caries with untreated clinical diagnosis was $45 \%$. Similarly, a study by Skinner et al. ${ }^{20}$ conducted in New South Wales, Australia, showed that $44.4 \%$ of adolescents had experience in caries in at least one tooth. However, it was slightly higher when compared to other studies, such as those by Ferreira et al..$^{22}$ and Ferreira et $a l .{ }^{25}$, both conducted in Piracicaba, São Paulo, Brazil, which showed that $23.3 \%$ and $22.32 \%$ of the adolescents presented with untreated carious lesion, respectively. However, the prevalence was lower than the findings of the capital, Porto Alegre, where the experience of untreated dental caries was high, with $63.1 \%$, and in the southern region of Brazil, which was $60.7 \%{ }^{15}$. Thus, it can be observed that the students of the municipalities surveyed had better results than the studies carried out in the South of the Country.

In addition, in the present study, $32.5 \%$ reported having suffered toothache in the last 6 months, similar time to results found by other authors, such as Schuch et $a l .{ }^{4}$ in Pelotas, RS, where the prevalence of dental 
pain was of $35.7 \%$, and Noro et al. 26 , made in Sobral, $\mathrm{CE}$, where the prevalence of toothache was $31.8 \%$ in the last 6 months. This prevalence should be considered high when compared to the following studies: Freire et al..$^{27}$ performed in 26 capitals of Brazilian states and in the Federal District, where the prevalence of toothache was $17.8 \%$; Jaiswal et al. ${ }^{28}$, in Kollipara Mandal, Guntur district, Andhra Pradesh, India, whose prevalence of toothache was $28.3 \%$; Rosa et al. ${ }^{29}$, performed in 36 municipalities with up to 50,000 inhabitants in Rio Grande do Sul, where $29.8 \%$ reported having toothache in the last 6 months. In turn, it is inferior to the results of the study carried out in Santa Maria, RS, where they found a prevalence of toothache in the last 6 months in $63.2 \%$ of students ${ }^{30}$ and in Leh, Ladakh, India, which showed that the prevalence of pain in the last 6 months was $77 \%{ }^{31}$. In the literature, different periods of time can be observed to investigate the experience of dental pain, some shorter, such as 4 weeks, which reduce bias risks. However, in longer periods, such as 6 months and 1 year, pain resulting from a chronic disease can be evaluated, as described by Schuch et al. ${ }^{4}$ in which, as in the present study, a period of 6 months. The prevalence of dental pain is a measure of quality of life and one of the indicators of oral health. Its reduction is one of the objectives of the 2020 global oral health goals ${ }^{32}$.

The untreated tooth decay experience had a statistically significant association with the toothache variables in the last 6 months, with $76 \%$ of those who had toothache in the last 6 months and caries present $(\mathrm{p}=0.012)$. In the study by Rihs et $a l .{ }^{33}$ conducted in Paulínia, SP, students who reported dental pain had a higher DMFT index and, as a consequence, a greater need for treatment, saying that pain in recent months was related to schoolchildren with worse oral health conditions. Our results still corroborate with the findings of Lopes et al. ${ }^{10}$ carried out in São Paulo, SP, which observed an association between untreated dental caries in children who had pain in the last 6 months. caries not treated as being of African descent, from public schools, with income equal to or less than a minimum wage and living in housing with a high family density. The study by Rosa et al. ${ }^{29}$ conducted in 36 municipalities with up to 50,000 inhabitants in Rio Grande do Sul, showed that adolescents with dental caries reported having up to twice as much toothache as those without dental caries. Authors describe that quality of life related to oral health and dental pain was associated with school absenteeism in 12-yearold adolescents. The authors describe that, in every 20 children, at least one report school absence due to toothache ${ }^{5}$. Therefore, the present study observed that school adolescents with untreated tooth decay presented dental pain in the last 6 months, which was similar to other regions of the State and the Country, which may cause oral health impacts of adolescents in society.
Noro et al. ${ }^{26}$ described that the fear of dental surgeons and dental procedures are still experienced by a large part of the population. Because of this, adolescents are likely to seek fewer dental services because of their distrust of dentists and the high anxiety associated with fear of procedures. According to the authors, these elements explain the irregular pattern of dental care in adolescents. In the present study, another variable that was associated with untreated caries was the perception of the treatment in the last consultation, $84.6 \%$ of whom found the treatment to be poor or regular, and caries present $(p=0.021)$. It can be assumed that fear and anxiety cause adolescents to describe dental treatment as bad or regular, frequent less the dentist and, as a consequence, have more untreated tooth decay. Corroborating this statement, Schuch et $a l .{ }^{4}$ described that patients with fear are more likely to postpone treatment, thus leading to more extensive dental problems.

The study has the design as a limitation, especially since it does not allow cause-effect inferences among dental caries factors, and because it does not allow follow-up of the examined ones, as in most cross-sectional studies ${ }^{2,3,24,34,35}$. It suggests thus, the next studies are carried out with a different methodological approach, such as a cohort study that allows cause-effect inferences with the factors related to dental caries.

The research has a great social relevance, since it approached a sample of school adolescents of two interior municipalities of the northwest region of Rio Grande do Sul. The determination of the oral health status, through this survey, contributes and allows the public sector to take cognizance and develop strategies to prevent wider problems, and may reduce the pathologies investigated.

The contribution of this research to the field of public health of the municipalities is inediticidade in carrying out an epidemiological research with oral exams in the students, thus describing a prevalent oral complaint and its need for treatment.

\section{CONCLUSION}

From the obtained results, it was possible to conclude that:

- average dental caries is low in schoolchildren of both municipalities, however, with a high prevalence of untreated dental caries;

- there was an association between the presence of toothache in the last six months and the perception of dental treatment in the last consultation with the presence of untreated dental caries, being the toothache and the absence of quality in dental treatment the factors that most impacted. 
1. Alves Filho P, Santos RV, Vettore MV. Fatores associados a cárie dental e doença periodontal em indígenas na América Latina: revisão sistemática. Rev Panam Salud Publica. 2014;35(1):67-77.

2. Freire MCM, Reis SCGB, Figueiredo N, Peres KG, Moreira RS, Antunes JLF. Determinantes individuais e contextuais da cárie em crianças brasileiras de 12 anos em 2010. Rev Saúde Pública. 2013;47(Supl.3):40-9. DOI: http://dx.doi.org/10.1590/S0034-8910.2013047004322

3. Ferraz NKL, Nogueira LC, Pinheiro MLP, Marques LS, Ramos-Jorge ML, Ramos-Jorge J. Clinical consequences of untreated dental caries and toothache in preschool children. Pediatr Dent. 2014;36(5):389-92.

4. Schuch HS, Correa MB, Torriani DD, Demarco FF, Goettems ML. Perceived Dental Pain: Determinants and Impact on Brazilian Schoolchildren. J Oral Facial Pain Headache. 2015;29(2): 168-6. DOI: http://dx.doi.org/10.11607/ofph.1414

5. Krisdapong S, Prasertsom P, Rattanarangsima K, Sheiham A. School absence due to toothache associated with sociodemographic factors, dental caries status, and oral health-related quality of life in 12- and 15-year-old Thai children. J Public Health Dent. 2013;73(4):321-8. DOI: http://dx.doi.org/10.1111/jphd.12030

6. Rigo L, Caldas Júnior AF, Souza EHA. Experiência de Cárie Dentária e Fatores Associados em Escolares de um Município com Fluoretação na Água. Pesq Bras Odontoped Clín Integr. 2011;11(3):407-15.

7. Meneghim MC, Kozlowski FC, Pereira AC, Ambrosano GMB, Meneghim ZMAP. Classificação socioeconômica e sua discussão em relação à prevalência de cárie e fluorose dentária. Ciênc Saúde Coletiva. 2007;12(2):523-9. DOI: http://dx.doi.org/10.1590/S1413-81232007000200028

8. Galindo EMV, Pereira JAC, Feliciano KVO, Kovacs MH. Prevalência de cárie e fatores associados em crianças da comunidade do Vietnã, Recife. Rev Bras Saude Mater Infant. 2005;5(2):199-208. DOI: http://dx.doi.org/10.1590/S1519-38292005000200009

9. Costa SM, Abreu MHNG, Vasconcelos M, Lima RCGS, Verdi M, Ferreira EF. Desigualdades na distribuição da cárie dentária no Brasil: uma abordagem bioética. Ciênc Saúde Coletiva. 2013; 18(2):461-70. DOI: http://dx.doi.org/10.1590/S1413-81232013000200017

10. Lopes RM, Domingues GG, Junqueira SR, Araujo ME, Frias AC. Conditional factors for untreated caries in 12-year-old children in the city of São Paulo. Braz. Oral Res. 2013;27(4):376-8. DOI: http://dx.doi.org/10.1590/S1806-83242013000400008

11. Instituto Brasileiro de Geografia e Estatística (IBGE). Indicadores. [cited 2017 Mar 30] Available from: http://ibge.gov.br/home/.

12. Klein H, Palmer CE. Dental caries in American indian children. Publ HIth Bull. 1937;239:1-54.

13. Brasil. Ministério da Saúde. Secretaria de Atenção à Saúde. Departamento de Atenção Básica Coordenação Nacional de Saúde Bucal. SB Brasil 2010: Pesquisa Nacional de Saúde Bucal. Manual do coordenador municipal. Brasília: 2009.

14. Rede Interagencial de Informação para a Saúde (RIPSA). Indicadores básicos para a saúde no Brasil: conceitos e aplicações. 2ed. Brasília: Organização Pan-Americana da Saúde, 2008; p.349.

15. Brasil. Ministério da Saúde. Secretaria de Atenção à Saúde. Secretaria de Vigilância em Saúde. SB Brasil 2010: Pesquisa Nacional de Saúde Bucal: resultados principais. Brasília: Ministério da Saúde, 2012.

16. Rihs LB, Sousa MLR, Cypriano S, Abdalla NM. Desigualdades na distribuição da cárie dentária em adolescentes de Indaiatuba (SP), 2004. Ciênc Saúde Coletiva. 2010;15(4):2173-80. DOI: http://dx.doi.org/10.1590/S1413-81232010000400031

17. Hoffmann RHS, Cypriano S, Sousa MLR, Wada RS. Experiência de cárie dentária em crianças de escolas públicas e privadas de um município com água fluoretada. Cad Saúde Pública. 2004; 20(2):522-8. DOI: http://dx.doi.org/10.1590/S0102-311X2004000200020

18. Moreira PVL, Rosenblatt A, Passos IA. Prevalência de cárie em adolescentes de escolas públicas e privadas na cidade de João Pessoa, Paraíba, Brasil. Ciênc Saúde Coletiva. 2007;12(5): 1229-36. DOI: http://dx.doi.org/10.1590/S1413-81232007000500020

19. Geus JL, Luca CMB, Baldani MH, Czlusniak GD. Prevalência de Cárie e Autopercepção da Condição de Saúde Bucal entre Crianças de Escolas Urbanas e Rurais de Ponta Grossa-PR. Pesq Bras Odontoped Clin Integr. 2013;13(1):111-17. 
20. Skinner J, Johnson G, Blinkhorn A, Byun R. Factors associated with dental caries experience and oral health status among New South Wales adolescents. Aust N Z J Public Health. 2014;38 (5):485-9. DOI: http://dx.doi.org/10.1111/1753-6405.12245

21. Brasil. Atlas do Desenvolvimento Humano no Brasil. Disponível em: http://www.atlasbrasil.org. br/2013/. Acesso em: 09 maio 2017.

22. Ferreira LL, Brandão GAM, Garcia G, Costa LST, Ambrosano GMB, Possobon RF. Odontalgia associada a variáveis socioeconômicas, psicossociais e saúde bucal. Rev Dor. 2012; 13(4):343-9. DOI: http://dx.doi.org/10.1590/S1806-00132012000400007

23. Junqueira SR, Frias AC, Zilbovicius $C$, Araujo ME. Saúde bucal e uso dos serviços odontológicos em função do Índice de Necessidades em Saúde: São Paulo, 2008. Ciênc Saúde Coletiva. 2012;17(4):1015-24. DOI: http://dx.doi.org/10.1590/S1413-81232012000400023

24. Santin GC, Pintarelli TP, Fraiz FC, Oliveira ACB, Paiva SM, Ferreira FM. Association between untreated dental caries and household food insecurity in schoolchildren. Ciênc Saúde Coletiva. 2016;21(2):573-84. DOI: http://dx.doi.org/10.1590/1413-81232015212.00022015

25. Ferreira LL, Brandão GAM, Garcia G, Batista MJ, Costa LST, Ambrosano GMB, et al. Coesão familiar associada à saúde bucal, fatores socioeconômicos e comportamentos em saúde. Ciênc Saúde Coletiva. 2013;18(8):2461-73. DOI: http://dx.doi.org/10.1590/S1413-81232013000800031

26. Noro LR, Roncalli AG, Mendes Júnior FI, Lima KC, Teixeira AKM. Toothache and social and economic conditions among adolescents in Northeastern Brazil. Ciênc Saúde Coletiva. 2014;19(1):105-14. DOI: http://dx.doi.org/10.1590/1413-81232014191.2110

27. Freire MCM, Leles CR, Sardinha LMV, Paludetto Junior M, Malta DC, Peres MA. Dor dentária e fatores associados em adolescentes brasileiros: a Pesquisa Nacional de Saúde do Escolar (PeNSE), Brasil, 2009. Cad Saúde Pública. 2012;28( Suppl ):S133-45. DOI: http://dx.doi.org/10.1590/S0102-311X2012001300014

28. Jaiswal AK, Pachava S, Sanikommu S, Rawlani SS, Pydi S, Ghanta B. Dental pain and self-care: a cross-sectional study of people with low socio-economic status residing in rural India. Int Dent J. 2015;65(5):256-60. DOI: http://dx.doi.org/10.1111/idj.12180

29. Rosa AR, Abegg C, Ely HC. Sense of coherence and toothache of adolescents from southern Brazil. J Oral Facial Pain Headache. 2015;29(3):250-6. DOI: http://dx.doi.org/10.11607/ofph.1383

30. Knackfuss AP, Costenaro RGS, Zanatta FB. Dor odontológica e indicadores de risco em jovens. Rev Gaucha Odontol. 2011;59(2):185-91.

31. Shekhawat KS, Chauhan A, Nordstroem M. Dental pain and its impact on quality of life among indigenous adolescents of Himalayas (Ladakh), India. Indian J Dent Res. 2016;27(1):22-6. DOI: http://dx.doi.org/10.4103/0970-9290.179809

32. Pau A, Khan SS, Babar MG, Croucher R. Dental pain and care-seeking in 11-14-yrold adolescents in a low-income country. Eur J Oral Sci. 2008;116:451-7. DOI: http://dx.doi.org/10.1111/j.1600-0722.2008.00563.x

33. Rihs LB, Cypriano S, Sousa MLR, Silva RC, Gomes PR. Dor de dente e sua relação com a experiência de cárie em adolescentes. Rev Gaucha Odontol. 2008;56(4):361-5.

34. Boeira GF, Correa MB, Peres KG, Peres MA, Santos IS, Matijasevich A, et al. Caries Is the Main Cause for Dental Pain in Childhood: Findings from a Birth Cohort. Caries Res. 2012;46(5): 488-95. DOI: http://dx.doi.org/10.1159/000339491

35. Peres KG, Cascaes AM, Leão ATT, Côrtes MIS, Vettore MV. Aspectos sociodemográficos e clínicos da qualidade de vida relacionada à saúde bucal em adolescentes. Rev Saúde Pública. 2013;47(3):19-28. DOI: http://dx.doi.org/10.1590/S0034-8910.2013047004361 


\section{Resumo}

Introdução: A cárie dentária é um grande problema de saúde pública em todo o mundo, pois pode causar dor e sofrimento aos indivíduos. Mesmo com um declínio da doença em crianças nos últimos anos, é observado em muitos países.

Objetivo: O objetivo desta pesquisa é analisar a média de cárie dentária e a prevalência de cárie não tratada e fatores associados em escolares da região Sul do Brasil.

Método: A abordagem do estudo é quantitativa, cujo delineamento é de corte transversal. A amostra foi composta por 77 adolescentes das escolas estaduais da zona urbana dos municípios de Ciríaco e David Canabarro, RS. Para a coleta de dados, foram realizados exames clínicos, utilizando o índice CPOD, e a aplicação de dois questionários semiestruturados dirigidos aos adolescentes e a seus pais. Os dados foram analisados individualmente, primeiramente por estatística descritiva e, posteriormente, por estatística inferencial ao teste do qui-quadrado de Pearson e de ANOVA, ao nível de significância de $5 \%$.

Resultados: A prevalência de cárie dentária não tratada na amostra final foi de $40,3 \%$ e a média de dentes com experiência de cárie, medida pelo índice CPOD (média de dentes cariado, perdidos e obturados) foi 2,32 , não havendo diferença estatística entre os municípios. Houve relação estatisticamente significativa entre a variável dor de dente nos últimos seis meses e o desfecho cárie não tratada $(p=0,012)$ com $76 \%$ dos que tiveram dor. Também houve associação entre a variável percepção do tratamento na última consulta e cárie não tratada $(p=0,021)$ com $84,6 \%$ adolescentes que consideraram o tratamento ruim/regular.

Conclusão: A média de cárie dentária foi baixa, porém, muitos adolescentes possuem dentes cariados sem tratamento, sendo a dor de dente e a ausência de qualidade no tratamento odontológico os fatores que mais impactaram.

Palavras-chave: cárie dentária, índice CPO, odontalgia, tratamento odontológico.

๑ The authors (2018), this article is distributed under the terms of the Creative Commons Attribution 4.0 International License (http:// creativecommons.org/licenses/by/4.0/), which permits unrestricted use, distribution, and reproduction in any medium, provided you give appropriate credit to the original author(s) and the source, provide a link to the Creative Commons license, and indicate if changes were made. The Creative Commons Public Domain Dedication waiver (http://creativecommons.org/publicdomain/zero/ $1.0 /)$ applies to the data made available in this article, unless otherwise stated. 